Florentinus SR, Hulten R van, Kramer M, van Dijk L, Heerdink ER, Leufkens HG, Groenewegen PP. Which pharmacists contribute to high-level pharmacotherapy audit meetings with general practitioners? Annals of Pharmacotherapy: 40, 2006, nr. 9, p. 1640-1646

\begin{tabular}{|c|c|}
\hline Postprint Version & 1.0 \\
\hline Journal website & http://www.theannals.com \\
\hline Pubmed link & $\begin{array}{l}\text { http://www.ncbi.nlm.nih.gov/entrez/query.fcgi?db=pubmed\&cmd=Retrieve\&dop } \\
\mathrm{t}=\text { AbstractPlus\&list_uids=16912245\&query_hl=5\&itool=pubmed_docsum }\end{array}$ \\
\hline DOI & 10.1345/aph.1H180. \\
\hline
\end{tabular}

This is a NIVEL certified Post Print, more info at http://www.nivel.eu

\title{
Which Pharmacists Contribute to High-Level Pharmacotherapy Audit Meetings with General Practitioners?
}

STEFAN R FLORENTINUS ${ }^{1}$, ROLF VAN HULTEN ${ }^{2}$, MARJOLEIN KRAMER ${ }^{3}$, LISET VAN DIJK ${ }^{4}$, EIBERT R HEERDINK $^{5}$, HUBERT GM LEUFKENS ${ }^{6}$, AND PETER P GROENEWEGEN ${ }^{7}$

${ }^{1}$ PharmD PhD, Junior Researcher, Division of Pharmacoepidemiology and Pharmacotherapy, Faculty of Science, Utrecht Institute for Pharmaceutical Sciences, Utrecht University, Utrecht, Netherlands

${ }^{2}$ PharmD PhD, Senior Researcher, Division of Pharmacoepidemiology and Pharmacotherapy, Faculty of Science, Utrecht Institute for Pharmaceutical Sciences, Utrecht University

${ }^{3} \mathrm{MSc}$, Senior Researcher, Division of Pharmacoepidemiology and Pharmacotherapy, Faculty of Science, Utrecht Institute for Pharmaceutical Sciences, Utrecht University

${ }^{4} \mathrm{PhD}$ MSc Pharmaceutical Science Student, Netherlands Institute for Health Services Research, Utrecht, Netherlands

${ }^{5} \mathrm{PhD}$, Assistant Professor, Division of Pharmacoepidemiology and Pharmacotherapy, Utrecht Institute for Pharmaceutical Sciences, Utrecht University

${ }^{6}$ Hubert GM Leufkens PharmD PhD, Professor, Division of Pharmacoepidemiology and Pharmacotherapy, Faculty of Science, Utrecht Institute for Pharmaceutical Sciences, Utrecht University

${ }^{7} \mathrm{PhD}$, Professor, Netherlands Institute for Health Services Research; Department of Sociology and Department of Human Geography, Utrecht University

*Reprints: Dr. Heerdink, Division of Pharmacoepidemiology and Pharmacotherapy, Faculty of Science, Utrecht Institute for Pharmaceutical Sciences, Utrecht University, PO Box 80.082, 3508 TB Utrecht, Netherlands, fax 003130253 9166, e.r.heerdink@pharm.uu.nl

Background: In the Netherlands, community pharmacists and general practitioners (GPs) collaborate in pharmacotherapy audit meetings (PTAMs) to optimize pharmacotherapy.

Objective: To identify associations between the quality level of PTAMs and characteristics of pharmacists.

Methods: We used a cross-sectional questionnaire design in a Dutch general practice and community pharmacy setting to estimate the contribution of pharmacists to the quality level of PTAMs. The questionnaire was sent to 123 community pharmacies working closely with 104 GP practices. The outcome variable was the quality level of PTAMs. The questionnaire provided information on 4 topics that were used as independent variables: characteristics of the PTAMs, provision of pharmacotherapy activities, characteristics of the pharmacists, and characteristics of the pharmacies.

Results: In total, 109 (88.6\%) pharmacists completed the questionnaire, with 103 participating in 62 different PTAMs. Seventeen pharmacists participated in level 1 PTAMs (lowest level), 57 in level 2, 21 in level 3, and 8 in PTAMs at the highest level. The multinomial logistic regression identified only one significant association: pharmacists who participated in the highest quality level reported that they undertake 
initiatives in PTAMs (OR 2.98; 95\% CI 1.07 to 8.26) more frequently compared with pharmacists participating on the lowest level.

Conclusions: In light of existing evidence, the role of pharmacists in PTAMs seems to be important. Pharmacists should create a distinct profile of their expertise, allowing them to professionalize PTAMs by undertaking more initiatives. PTAMs offer pharmacists a great opportunity to become integral members of the prescribing process.

\section{EXTRACTO}

Introducción: En los Países Bajos, los farmacéuticos comunitarios, y los médicos generales (GPs) colaboran en reuniones para auditar la farmacoterapia (PTAMs) orientadas a optimizar la farmacoterapia.

Objetivo: Encontrar asociaciones entre el nivel de calidad de las PTAMs y las características de los farmacéuticos.

Métodos: Se realizó un estudio transversal mediante un cuestionario en un entorno de atención primaria y farmacias comunitarias en los Países Bajos para estimar la contribución de los farmacéuticos al nivel de calidad de los PTAMs. El cuestionario fue enviado a 123 farmacias comunitarias que trabajan en estrecha relación con 104 consultas de GP. La variable dependiente fué el nivel de calidad de los PTAMs. El cuestionario facilitaba información sobre 4 aspectos que se consideraron variables independientes: las características de los PTAMs, la prestación de actividades de atención farmacéutica a los pacientes, las características de los farmacéuticos, y las características de las farmacias.

Resultados: Completaron el cuestionario un total de 109 (88.6\%) farmacéuticos. Ciento tres farmacéuticos participaban en 62 PTAMs diferentes. Diecisiete farmacéuticos en PTAMs de nivel 1 (el más bajo), 57 en PTAMs de nivel 2, 21 en PTAMs de nivel 3, y 8 en PTAMs del nivel más alto. La regresión logística multinomial identificó sólo una asociación significativa: los farmacéuticos que participaban en el nivel de calidad más alto respondieron que emprendían iniciativas en los PTAMs con mayor frecuencia (OR 2.98; 95\% CI 1.07 y 8.26) que los que participaban en los de nivel más bajo.

Conclusiones: A la luz de las pruebas disponibles, el papel de los farmacéuticos en los PTAMs parece ser importante. Los farmacéuticos deberían crear un perfil diferenciado de su especialización y pueden profesionalizar los PTAMs asumiendo más iniciativas. Los PTAMs ofrecen a los farmacéuticos una gran oportunidad de convertirse en miembros integrales del proceso de prescipción.

Juan del Arco

\section{RÉSUMÉ}

Objectif: Évaluer s'il existe une association entre la qualité des révisions de la pharmacothérapie lors des rencontres avec les médecins et les caractéristiques des pharmaciens qui effectuent ces révisions.

Méthodologie: Les auteurs ont utilisé un questionnaire dans un devis de coupe transversale chez des médecins hollandais en pratique générale et des pharmaciens de ville pour évaluer la contribution des pharmaciens dans la qualité des révisions en pharmacothérapie. Le questionnaire a été envoyé à 123 pharmacies de ville qui travaillent en étroite collaboration avec des médecins de pratique générale. Le principal critère de jugement était la qualité des révisions en pharmacothérapie effectuée par les pharmaciens de ville. Quatre différents thèmes ont été regroupés dans le questionnaire et ces thèmes 
Florentinus SR, Hulten R van, Kramer M, van Dijk L, Heerdink ER, Leufkens HG, Groenewegen PP. Which pharmacists contribute to high-level pharmacotherapy audit meetings with general practitioners? Annals of Pharmacotherapy: 40, 2006, nr. 9, p. 1640-1646

ont été utilisés comme variables indépendantes, soit les caractéristiques des révisions en pharmacothérapie, la dispensation des soins pharmaceutiques, les caractéristiques des pharmaciens, et les caractéristiques des pharmacies.

Résultats: Un nombre de 109 (88.6\%) pharmacies ont complété le questionnaire. Les 103 pharmaciens ont participé dans 62 différentes activités de révision de pharmacothérapie. Dix-sept pharmaciens ont participé au niveau 1 dans les rencontres de révision de la pharmacothérapie (plus bas niveau), 57 pharmaciens au niveau 2, 21 pharmaciens au niveau 3, et 8 pharmaciens au niveau le plus élevé. Une analyse multivariée à l'aide d'une régression logistique a identifié une seule association statistiquement significative, soit que les pharmaciens qui ont participé au niveau le plus élevé ont rapporté plus fréquemment qu'ils étaient proactifs dans la révision de la pharmacothérapie (OR 2.98; 95\% CI 1.07 à 8.26), comparativement aux pharmaciens qui ont participé au plus bas niveau.

Conclusions: Le rôle du pharmacien lors des rencontres de révision de pharmacothérapie semble être important. Les pharmaciens doivent cependant créés un profil distinct de leur expertise et devraient être proactifs dans leurs interventions. La révision de la pharmacothérapie permet aux pharmaciens de devenir un membre actif du processus de prescription.

Louise Mallet

Increasing interest exists among healthcare professionals to optimize care for patients by applying a teamwork approach. ${ }^{1-3}$ Community pharmacists, for example, are challenged to become important players in the prescribing process or even prescribers of drugs themselves. ${ }^{2,4,5}$ With the development of pharmacotherapy, the pharmacist's attention has shifted from medicine preparation to more patientoriented services. ${ }^{6}$ Based on findings reported in current literature, it can be assumed that the pharmacist's contribution to the quality of pharmacotherapy increases as cooperation with general practitioners (GPs) improves. ${ }^{7-9}$ In several countries, this process has led to closer collaborations between GPs and pharmacists. ${ }^{10,11}$

In the Netherlands, GPs and community pharmacists practicing in the same catchment area regularly organize pharmacotherapy audit meetings (PTAMs) to optimize pharmacotherapy. ${ }^{12}$ PTAMs are defined as a series of regular meetings between GPs and pharmacists, during which information and views about pharmacotherapy are exchanged with the aim being to improve the prescribing and dispensing of drugs. ${ }^{13}$ In 2003, 794 PTAMs were active in the Netherlands, meaning that nearly all GPs and community pharmacists participated in the meetings. ${ }^{14}$

PTAMs are classified into 4 levels based on the capability to make decisions about pharmacotherapy, for example, about which drugs are first-choice treatment in the treatment of primary hypercholesterolemia. The 4 levels are: 1 (no structured meetings), 2 (frequent meetings without concrete decisions), 3 (frequent meetings with concrete decisions), and 4 (frequent meetings with concrete decisions and evaluation of those decisions). ${ }^{13}$

The concept of the 4 quality levels was introduced by the Netherlands Institute for Health Services Research (NIVEL) in 2001 and further developed by the Dutch Institute for the Proper Use of Medicine (DGV) in 2003 in terms of minimal requirements for each level. ${ }^{13,15,16}$ Indicators refer to structure and process of the PTAM and its meetings and to whether agreements are made and evaluated. As of now, the DGV uses this system to evaluate all PTAMs in the Netherlands annually and actively stimulate PTAMs to function at a higher quality level.

Studies on the quality and effectiveness of PTAMs noted that the quality was strongly influenced by the organization and ethos of the meetings. ${ }^{13}$ De Vries ${ }^{17}$ noted that $45 \%$ of the PTAMs had a limited effect on GPs' prescribing behavior. Muijrers et al. ${ }^{18}$ reported that, although GPs and pharmacists have fruitful collaborations, PTAMs had no measurable effect on the quality of prescribing of GPs working in a solo practice. Despite the valuable contributions of the studies on the effectiveness of PTAMs, limited data are available on the profile of pharmacists contributing to high-level PTAMs. 
To elucidate the contributions of pharmacists to the quality of these meetings, we hypothesized that the quality level of PTAMs can be strongly influenced by the efforts of pharmacists who have a special interest in PTAMs. This interest, together with other characteristics, may be concentrated in pharmacists with a distinct profile, such as a patient-focused or care-providing orientation. Therefore, the purpose of the present study was to examine the associations between the quality level of PTAMs and the characteristics of pharmacists.

\section{METHODS}

\section{Setting}

This study was performed in a network of 123 community pharmacies that participated in a larger study on new drug prescribing by GPs, which was conducted by the Utrecht Institute for Pharmaceutical Sciences of Utrecht University. The participating pharmacies had to work closely with 104 GP practices that participated in the second Dutch national survey of general practice, conducted by NIVEL in $2001 .{ }^{19}$ Data on PTAMs were collected through a questionnaire sent to all participating pharmacies in December 2003. All initial nonresponders received a reminder letter and a phone call 2 weeks after the questionnaire was mailed.

\section{Variables And Instruments}

The questionnaire was created based on discussions within the research team and existing questionnaires. ${ }^{13,19}$ Previous studies of PTAMs provided limited information on characteristics of pharmacists that were important to validate our hypothesis. Therefore, the final questionnaire was formulated based on the comments of experts and was tested by 7 practicing community pharmacists. The final questionnaire included 4 topics:

1. Characteristics of the PTAMs. The pharmacist who was most actively involved in the PTAMs completed this part of the questionnaire. The purpose was to measure the quality, composition, and content of the PTAMs and the pharmacy's involvement.

2. The provision of medication management activities. ${ }^{6}$ The pharmacist responsible for coordinating these activities completed this section to determine the quantity and content of those services.

3. Characteristics of the pharmacists. All pharmacists working in the pharmacy filled in this section. Several characteristics were assessed, including the pharmacist's attitude toward "pharmacists as health professionals," "pharmacists as entrepreneurs," "pharmaceutical patient care," and "newly marketed drugs." Furthermore, we determined their general perceived self-efficacy scale ${ }^{20}$ and initiatives in PTAMs. All attitudes were measured by using a 5 point Likert scale (Appendix I).

4. Practice characteristics: ownership of the pharmacy, presence of consulting room, and being part of a chain pharmacy.

\section{[ APPENDIX 1 ]}

Factor analysis with a varimax rotation procedure was used to verify whether the different questions related to the pharmacist's attitude identified a single construct. Cronbach's alphas were calculated for the different constructs to ensure sufficient internal consistency in the questions. Questions related to one construct were used to calculate sum scores that were used in the analysis (Appendix I).

\section{Analysis}

To identify characteristics of pharmacists associated with the quality level of PTAMs, we used a multinomial logistic regression model. The primary outcome variable was the quality level of the PTAMs as perceived and reported by pharmacists in the questionnaire. The classification of the PTAMs into 4 quality levels based on their capability to make decisions is the gold standard. ${ }^{13}$ When more than one pharmacist attended the same PTAM and they differed in their assessment, each pharmacist was considered to participate on the lowest reported level as reported by one of the respondents. This ensured that the effect of the PTAMs was not overestimated.

Odds ratios with 95\% confidence intervals were estimated for the different pharmacist characteristics per PTAM levels, with the lowest level (level 1) as the reference level. 
Florentinus SR, Hulten R van, Kramer M, van Dijk L, Heerdink ER, Leufkens HG, Groenewegen PP. Which pharmacists contribute to high-level pharmacotherapy audit meetings with general practitioners? Annals of Pharmacotherapy: 40, 2006, nr. 9, p. 1640-1646

\section{RESULTS}

In total, 109 (88.6\%) pharmacists completed the questionnaire. Five pharmacists worked in a facility that did not participate in PTAMs with one of the 104 GP practices. Furthermore, one pharmacist was excluded due to missing data, leaving a total of 103 respondents to be included in the analysis.

The 103 pharmacists participated in 62 different PTAMs. Table 1 shows the quality level, composition, and content related to new drug prescribing of the PTAMs. On average $( \pm$ SD), the PTAMs consisted of $3.9 \pm 2.2$ pharmacists, working in $2.6 \pm 1.4$ pharmacies, and $10 \pm 3.7$ GPs. The majority (74.2\%) of the PTAMs made decisions about which drugs were first-choice treatment. Only 3 PTAMs never discussed newly marketed drugs. Although the majority did discuss newly marketed drugs, 42 did not make any decisions about which of these should or should not be prescribed. Pharmaceutical representatives were invited to attend 9 PTAMs; 8 PTAMs decided that only the pharmacist should receive visits of pharmaceutical representatives.

\section{[ TABLE 1 ]}

Of the pharmacists assigned to be the pharmacy's representative at the PTAMs, 54 were male, 76 were the managing pharmacist, and 42 were the pharmacy's owner (Table 2). In total, 17 pharmacists participated in level 1 PTAMs, 57 in level 2 PTAMs, 21 in level 3 PTAMs, and 8 in PTAMs on the highest level.

\section{[ TABLE 2 ]}

Multinomial logistic regression analysis identified a trend for the reported initiatives in PTAMs. Pharmacists who reported performing more initiatives were more likely to participate in a higher level PTAM. Pharmacists participating in PTAMs of the highest level reported undertaking initiatives significantly more often compared with pharmacists working with PTAMs of the lowest level (OR 2.98; 95\% CI 1.07 to 8.26). The initiatives included facilitating in the initial organization of PTAMS, functioning as chair, and preparing the content of the meetings.

\section{DISCUSSION}

The aim of this study was to determine characteristics of pharmacists associated with PTAMs of various quality levels. Although the GP-pharmacist interface has been evaluated, this is the first study to focus on the characteristics of pharmacists in relation to the quality of PTAMs. In this sense, our study makes a valuable contribution to research on the effect of pharmacists on GPs' prescribing behavior.

For PTAMs to results in decisions to optimize pharmacotherapy, the key prerequisite is a group of willing GPs and pharmacists. Studies have identified perceived interprofessional barriers between pharmacists and GPs. ${ }^{1,2,18}$ Muijrers et al. ${ }^{18}$ showed that the majority of GPs want pharmacists to have an advisory rather than a codetermining role in pharmacotherapy. Two aspects make it difficult for pharmacists to have extensive influence on the likelihood that decisions are being made. First, for PTAMS to reach at least level 3 , decisions have to be made, and consensus among participants is needed. This may be difficult to achieve for an individual pharmacist in a PTAM that is attended by GPs and a few other pharmacists. Second, pharmacists are not the ones who prescribe drugs and therefore do not have to conform to the decisions made during PTAMs. Assigning a codetermining role to pharmacists in the decision about which drugs are or are not prescribed means, in almost all cases, restriction of the GP's freedom to prescribe and assignment of a controlling function to pharmacists. This is something that not all GPs are willing to do ${ }^{18}$ The discrepancy is also reflected in the findings of other studies that identify differences in the perceptions of pharmacists and GPs regarding the quality level of the PTAMs. ${ }^{11,13,18}$ In general, pharmacists express a greater wish for more binding agreed policies and guidelines compared with GPs. ${ }^{11,13}$

Although previous findings on the effectiveness of PTAMs seem limited, we did note that pharmacists' selfreported initiatives regarding PTAMs were associated with the quality level of the PTAMs. Pharmacists who regularly undertake initiatives and fulfill an important role in the organization of PTAMs are clearly also those who participate in high-quality PTAMs. This is a clear 
indicator for pharmacists regarding the actions necessary to increase the quality level of the PTAMs they attend. Van Dijk et al. ${ }^{13}$ noted the quality of PTAMs to be strongly influenced by the organization and ethos of the meetings. Maintaining an open ethos, making and auditing concrete decisions, maintaining optimal balance between the length and frequency of the meetings, and assigning a chairman were important determinants of the final quality. Given the results of studies showing synergy when GPs and pharmacists work together, pharmacists should focus on 2 goals: positioning themselves more as experts in pharmacotherapy and expanding their involvement in PTAMs by facilitating in the organization of PTAMs.

Interestingly, the typical profile of a pharmacist who provides active care, namely, counseling at first and second dispensing, using a private consultation room, and inviting patients to discuss and optimize their medication, does not seem to be the profile of a pharmacist involved in highquality PTAMs. However, Storimans et al. ${ }^{21}$ showed that pharmacists working in close relationships with other healthcare providers provided more care for patients with diabetes. This finding might imply that pharmacists involved in high-quality PTAMs are indeed providing more care, but their extra services are limited to the areas in which agreements have been made during PTAMs. Highquality PTAMs discuss only a limited number of topics. ${ }^{22}$

New developments in community pharmacy, such as the forward integration of wholesale institutions that are buying retail pharmacies and the development of chain pharmacies, have fueled the discussion about efforts of pharmacists to provide care. However, our results do not show whether pharmacists working in facilities owned by wholesalers or in pharmacies consolidated into chains participated in a lower or higher quality of PTAMs.

\section{LIMITATIONS}

The results of our study need to be interpreted in light of its limitations. Although $88.6 \%$ of the pharmacists completed the questionnaire, the results are based on data as reported only by pharmacists. The findings would have been more robust had GPs been included in the sample. The most important limitation was the relatively limited number of pharmacists per PTAM level, especially on levels 1 and 4 . However, logistic regression analysis with the number of quality levels reduced to 2 (ie, levels 1 and 2 considered low-quality and levels 3 and 4 considered high-quality) PTAMs showed identical results.

Another limitation of our study is the possibility that the respondents indicated socially desirable answers. For example, pharmacists who reported to be a driving force behind the PTAMs may also have been likely to rate the quality of the meetings as high. However, although the quality was assessed by pharmacists alone, it was done according to objective criteria formulated by the NIVEL. ${ }^{13,16}$ The criteria are familiar to pharmacists in the Netherlands because they are used by the DGV each year to evaluate all PTAMs. ${ }^{15}$

\section{CONCLUSIONS}

In light of existing evidence, the role of pharmacists in PTAMs seems to be important, and pharmacists should expand their involvement by facilitating in the initial organization of PTAMs. However, given the differences in opinion between GPs and pharmacists concerning the role of pharmacists and the fact that pharmacists are outnumbered in PTAMs, pharmacists should create a distinct profile of their expertise and professionalize PTAMs by undertaking more initiatives. PTAMs offer pharmacists a great opportunity to become integral members of the prescribing process, but further research is recommended to determine which pharmacist-related factors are critical for fruitful PTAMs. 
Florentinus SR, Hulten R van, Kramer M, van Dijk L, Heerdink ER, Leufkens HG, Groenewegen PP. Which pharmacists contribute to high-level pharmacotherapy audit meetings with general practitioners? Annals of Pharmacotherapy: 40, 2006, nr. 9, p. 1640-1646

\section{TABLES}

\begin{tabular}{|c|c|c|}
\hline Parameter & $\mathrm{n}$ & $\%$ \\
\hline \multicolumn{3}{|l|}{ Quality level } \\
\hline 1 & 7 & 11.3 \\
\hline 2 & 33 & 53.2 \\
\hline 3 & 14 & 22.6 \\
\hline 4 & 8 & 12.9 \\
\hline \multicolumn{3}{|l|}{$\begin{array}{l}\text { Are decisions made about which drugs } \\
\text { are first choice during PTAMs? }\end{array}$} \\
\hline no & 16 & 25.8 \\
\hline yes, oral decisions & 16 & 25.8 \\
\hline yes, written decisions without feedback & 18 & 29.0 \\
\hline yes, written decisions with feedback & 12 & 19.4 \\
\hline \multicolumn{3}{|l|}{$\begin{array}{l}\text { Are drugs prescribed following a (regional) } \\
\text { formulary? }\end{array}$} \\
\hline no & 46 & 74.2 \\
\hline yes & 16 & 25.8 \\
\hline \multicolumn{3}{|l|}{$\begin{array}{l}\text { Are newly marketed drugs discussed } \\
\text { during PTAMs? }\end{array}$} \\
\hline no & 3 & 4.8 \\
\hline yes, sometimes & 29 & 46.8 \\
\hline yes, always & 30 & 48.4 \\
\hline \multicolumn{3}{|l|}{$\begin{array}{l}\text { Are decisions made about which new } \\
\text { drugs should or should not be prescribed? }\end{array}$} \\
\hline no & 42 & 67.7 \\
\hline yes, oral decisions & 12 & 19.4 \\
\hline yes, written decisions without feedback & 5 & 8.1 \\
\hline yes, written decisions with feedback & 3 & 4.8 \\
\hline \multicolumn{3}{|l|}{$\begin{array}{l}\text { Are prescribing data of GPs discussed } \\
\text { during PTAMs? }\end{array}$} \\
\hline no & 10 & 16.1 \\
\hline yes, sometimes & 45 & 72.6 \\
\hline yes, always & 7 & 11.3 \\
\hline \multicolumn{3}{|l|}{$\begin{array}{l}\text { Are pharmaceutical representatives } \\
\text { invited to attend PTAMs? }\end{array}$} \\
\hline no & 53 & 85.5 \\
\hline yes, sometimes & 8 & 12.9 \\
\hline yes, always & 1 & 1.6 \\
\hline \multicolumn{3}{|l|}{$\begin{array}{l}\text { Are decisions made during PTAMs about } \\
\text { who (GPs, pharmacists, both) } \\
\text { sees pharmaceutical representatives? }\end{array}$} \\
\hline no & 47 & 75.8 \\
\hline yes, both pharmacists and GPs & 7 & 11.3 \\
\hline yes, only pharmacists & 8 & 12.9 \\
\hline
\end{tabular}


Florentinus SR, Hulten R van, Kramer M, van Dijk L, Heerdink ER, Leufkens HG, Groenewegen PP. Which pharmacists contribute to high-level pharmacotherapy audit meetings with general practitioners? Annals of Pharmacotherapy: 40, 2006, nr. 9, p. 1640-1646

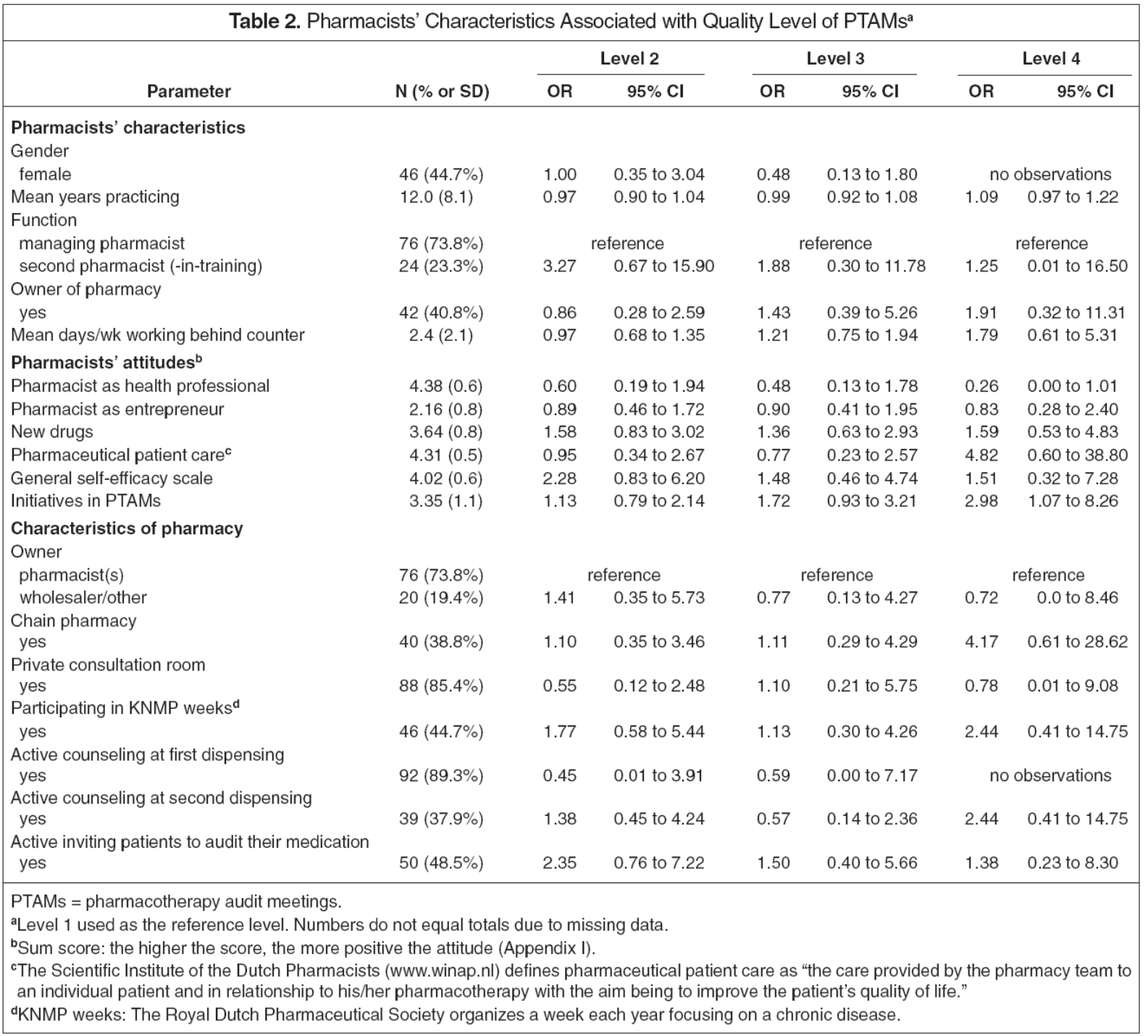

\section{REFERENCES}

1. Zillich AJ, McDonough RP, Carter BL, Doucette WR. Influential characteristics of physician/pharmacist collaborative relationships. Ann Pharmacother 2004;38:764-70. Epub 18 Mar 2004. DOI 10.1345/aph.1D419

2. Hughes $\mathrm{CM}, \mathrm{McC}$ ann S. Perceived interprofessional barriers between community pharmacists and general practitioners: a qualitative assessment. Br J Gen Pract 2003;53:600-6.

3. Guzman J, Esmail R, Karjalainen K, Malmivaara A, Irvin E, Bombardier C. Multidisciplinary rehabilitation for chronic low back pain: systematic review. BMJ 2001;322:1511-6.

4. Avery AJ, Pringle M. Extended prescribing by UK nurses and pharmacists. BMJ 2005;331:1154-5.

5. Medicines and Healthcare Products Regulatory Agency (MHRA) DoH. Consultation on proposals to introduce independent prescribing by pharmacists. www.dh.gov.uk/assetRoot/04/10/48/81/04104881.pdf (accessed 14 Nov 2005).

6. van Mil JWF, Schulz M, Tromp TFJD. Pharmaceutical care, European developments in concepts, implementation, teaching, and research: a review. Pharm World Sci 2004;26:30311.

7. Coast-Senior EA, Kroner BA, Kelley CL, Trilli LE. Management of patients with type 2 diabetes by pharmacists in primary care clinics. Ann Pharmacother 1998;32:636-41. DOI 10.1345/aph.17095

8. Leape LL, Cullen DJ, Clapp MD, et al. Pharmacist participation on physician rounds and adverse drug events in the intensive care unit. JAMA 1999;282:267-70.

9. Borenstein JE, Graber G, Saltiel E, et al. Physician-pharmacist comanagement of hypertension: a randomized, comparative trial. Pharmacotherapy 2003;23:209-16. 
Florentinus SR, Hulten R van, Kramer M, van Dijk L, Heerdink ER, Leufkens HG, Groenewegen PP. Which pharmacists contribute to high-level pharmacotherapy audit meetings with general practitioners? Annals of Pharmacotherapy: 40, 2006, nr. 9, p. 1640-1646

10. Bradley CP, Taylor RJ, Blenkinsopp A. Primary care-opportunities and threats. Developing prescribing in primary care. BMJ 1997;314:744-7.

11. Kocken GA. Medication discussion groups in the Netherlands: five years of experience. Med Educ 1999;33:390-3.

12. Blom AT, Paes AH, Bakker A, Koopman CJ, van der Meer C. Pharmacist- physician cooperation at a regional level. Pharm World Sci 1994; 16:13-7.

13. Van Dijk L, Barnhoorn H, De Bakker DH. [Pharmacotherapy audit meetings in 1999: the state of affairs] Dutch. Utrecht: NIVEL, 2001.

14. DGV. FTO-peiling 2003. [Dutch Institute for Effective Use of Medication]. www.medicijngebruik.nl/content/17_vind_op_thema/17-7-1.htm (accessed 2005 Aug 10).

15. DGV. FTO-peiling 2004 [Dutch Institute for Effective Use of Medication]. www.dgvinfo.nl/content/5_persberichten/5- 4.htm\#5 (accessed 2006 Aug 8).

16. Van Dijk L, de Bakker DH. Professionalization of Dutch PRGs and volume and costs of frequently prescribed drugs. Zeitschrift für Gesundheitswissenschaften 2002;10:292-304.

17. De Vries CS. Collaboration in healthcare; the tango to drug safety. Department of Social Pharmacy \& Pharmacoepidemiology, University Centre for Pharmacy, Groningen Institute for Drug Studies. Groningen: State University Groningen, 1998.

18. Muijrers PE, Knottnerus JA, Sijbrandij J, Janknegt R, Grol RP. Changing relationships: attitudes and opinions of general practitioners and pharmacists regarding the role of the community pharmacist. Pharm World Sci 2003;25:235- 41.

19. Westert GP, Schellevis FG, de Bakker DH, Groenewegen PP, Bensing JM, van der Zee J. Monitoring health inequalities through general practice: the Second Dutch National Survey of General Practice. Eur J Public Health 2005;15:59-65.

20. Schwarzer R. Self-efficacy: thought control of action. Washington, DC: Hemisphere, 1992.

21. Storimans MJ, Klungel OH, Talsma H, Bouvy ML, de Blaey CJ. Collaborative services among community pharmacies for patients with diabetes. Ann Pharmacother 2005;39:1647-53. Epub 6 Sept 2005. DOI 10.1345/aph.1G109

22. Pronk MC, Blom LT, Jonkers R, Rogers EM, Bakker A, de Blaey KJ. Patient oriented activities in Dutch community pharmacy: diffusion of innovations. PharmWorld Sci 2002;24:154-61. 
Florentinus SR, Hulten R van, Kramer M, van Dijk L, Heerdink ER, Leufkens HG, Groenewegen PP.

Which pharmacists contribute to high-level pharmacotherapy audit meetings with general practitioners?

Annals of Pharmacotherapy: 40, 2006, nr. 9, p. 1640-1646

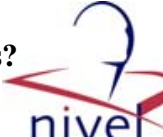

\section{APPENDIX}

\begin{tabular}{|c|c|c|c|c|c|c|}
\hline \multicolumn{7}{|c|}{ Appendix I. Results of the Reliability Analysis and the Survey Used to Calculate Sum Scores ${ }^{a}$} \\
\hline Parameter & $\begin{array}{l}\text { Factor } \\
\text { Loading }\end{array}$ & $\begin{array}{c}\text { Fully } \\
\text { Disagree (\%) }\end{array}$ & $\begin{array}{c}\text { Partly } \\
\text { Disagree (\%) }\end{array}$ & Neutral (\%) & $\begin{array}{c}\text { Partly } \\
\text { Agree }(\%)\end{array}$ & $\begin{array}{c}\text { Fully } \\
\text { Agree (\%) }\end{array}$ \\
\hline \multicolumn{7}{|l|}{$\begin{array}{l}\text { Attitude to "pharmacist as healthcare provider" } \\
\text { (Cronbach's } \alpha=0.75)\end{array}$} \\
\hline $\begin{array}{l}\text { The pharmacist primarily focuses on the } \\
\text { patient's well-being. }\end{array}$ & 0.82 & 1.1 & 1.1 & 5.0 & 32.8 & 60.0 \\
\hline $\begin{array}{l}\text { The pharmacist is primarily guided in his } \\
\text { management by what is essentially a } \\
\text { healthcare point of view. }\end{array}$ & 0.82 & 0.6 & 1.1 & 12.8 & 40.0 & 45.6 \\
\hline $\begin{array}{l}\text { The pharmacist is, in the first place, a link in } \\
\text { the healthcare system. }\end{array}$ & 0.67 & 1.7 & 1.1 & 9.4 & 27.8 & 60.0 \\
\hline $\begin{array}{l}\text { The pharmacist should always devote his } \\
\text { entrepreneurship to healthcare. }\end{array}$ & 0.73 & 1.1 & 7.8 & 13.4 & 40.2 & 37.4 \\
\hline \multicolumn{7}{|l|}{$\begin{array}{l}\text { Attitude to "pharmacist as entrepreneur" } \\
\text { (Cronbach's } \alpha=0.66 \text { ) }\end{array}$} \\
\hline $\begin{array}{l}\text { Pharmacists should take a purely business- } \\
\text { like position. }\end{array}$ & 0.80 & 29.1 & 35.8 & 22.3 & 11.7 & 1.1 \\
\hline $\begin{array}{l}\text { A good pharmacist is primarily an enterprising } \\
\text { pharmacist. }\end{array}$ & 0.80 & 21.9 & 27.5 & 24.7 & 23.6 & 2.2 \\
\hline $\begin{array}{l}\text { A pharmacy is comparable to other } \\
\text { commercial organizations } \\
\text { operating based on a profit motif. }\end{array}$ & 0.72 & 41.7 & 32.8 & 12.8 & 11.1 & 1.7 \\
\hline \multicolumn{7}{|l|}{ Attitude to "new drugs" (Cronbach's $\alpha=0.64$ ) } \\
\hline $\begin{array}{l}\text { Older drugs are in general as equally effective } \\
\text { as new drugs. }\end{array}$ & 0.66 & 4.5 & 19.6 & 30.2 & 38.5 & 7.3 \\
\hline $\begin{array}{l}\text { Prescribing of new drugs should occur with } \\
\text { restraint. }\end{array}$ & 0.81 & 16.2 & 46.4 & 27.9 & 8.9 & 0.8 \\
\hline New drugs are often "me-too's." & 0.82 & 2.2 & 12.8 & 20.0 & 49.4 & 15.6 \\
\hline \multicolumn{7}{|l|}{$\begin{array}{l}\text { Attitude to "pharmaceutical patient care" } \\
\text { (Cronbach's } \alpha=0.69)\end{array}$} \\
\hline $\begin{array}{l}\text { Pharmacists should focus more on providing } \\
\text { pharmaceutical patient care. }\end{array}$ & 0.66 & 66.3 & 28.6 & 4.1 & 1.0 & 0.0 \\
\hline $\begin{array}{l}\text { Pharmaceutical patient care ensures optimal } \\
\text { prescribing of drugs. }\end{array}$ & 0.81 & 26.5 & 44.9 & 18.4 & 6.1 & 4.1 \\
\hline $\begin{array}{l}\text { Active counseling at first and second } \\
\text { dispensing fulfills the information needs of } \\
\text { patients. }\end{array}$ & 0.82 & 53.6 & 41.2 & 5.2 & 0.0 & 0.0 \\
\hline \multicolumn{7}{|l|}{$\begin{array}{l}\text { Initiatives regarding PTAMs } \\
(\text { Cronbach's } \alpha=0.93)\end{array}$} \\
\hline I regularly undertake initiatives within the PTAM. & 0.82 & 7.3 & 9.6 & 23.2 & 29.4 & 30.5 \\
\hline $\begin{array}{l}\text { Without me, the PTAM will function at a lower } \\
\text { level. }\end{array}$ & 0.92 & 17.5 & 13.6 & 27.7 & 23.2 & 18.1 \\
\hline I am the driving force behind the PTAM. & 0.93 & 24.9 & 16.4 & 30.5 & 17.5 & 10.7 \\
\hline $\begin{array}{l}\text { Without me, less will be undertaken within the } \\
\text { PTAM. }\end{array}$ & 0.95 & 21.5 & 15.3 & 27.7 & 20.9 & 14.7 \\
\hline
\end{tabular}

